\title{
Mechanical Property Evaluation of Micro Cantilever Fabricated Using Micro-Stereolithography
}

\author{
Masafumi Miwa Member (Wakayama University,miw@sys.wakayama-u.ac.jp) \\ Hiroshi Kawaguchi Non-member (Wakayama University) \\ Kazuchika Douoka Non-member (Wakayama University) \\ Satoru Yoneyama Non-member (Osaka Prefecture University) \\ Shigeki Tuchitani Member (Wakayama University) \\ Yasuhiro Koshimoto Member (Wakayama University)
}

Keywords : 3D Micro Stereo Lithography, Elastic Modulus, Micro Cantilever, Micromachine

Micro-Stereolithography ( $\mu \mathrm{SL}$ ) is an excellent fabrication method which can create real three dimensional microstructures. In this method, laser beam is introduced to a microscope and is focused into photopolymer resin by an objective lens. Then, the photopolymerization is initiated near the focal point if sufficient energy is absorbed. By controlling the focus position, it can initiate photopolymerization at any point and create a microstructure three dimensionally. New types of micromachines, integrated microfluid sensors, and integrated photoelectronic devices, etc. were fabricated by $\mu \mathrm{SL}$. It is important to know mechanical properties of micro structures fabricated as a micro machine component. We developed new measurement equipment (Fig. 1) and measured elastic modulus of micro cantilevers (Fig. 2) fabricated by $\mu \mathrm{SL}$. Sample micro cantilevers were formed by changing irradiation laser power of $\mu \mathrm{SL}$ system and postcure processing time. A load was applied on the sample cantilever by a needle, then the relation between load and deflection of the cantilever was obtained. The elastic modulus of samples were evaluated from the gradient of the measured load-defection relation and the formula of strength of material. Table 1 shows the results. Experimental results show that the elastic modulus of the cantilever made by $\mu \mathrm{SL}$ is dependent on the irradiation laser power. In addition, it is found that the elastic modulus increases by postcure which makes progress of un-cured part polymerization in the cantilever. The increased values are also dependent on the irradiate laser power.

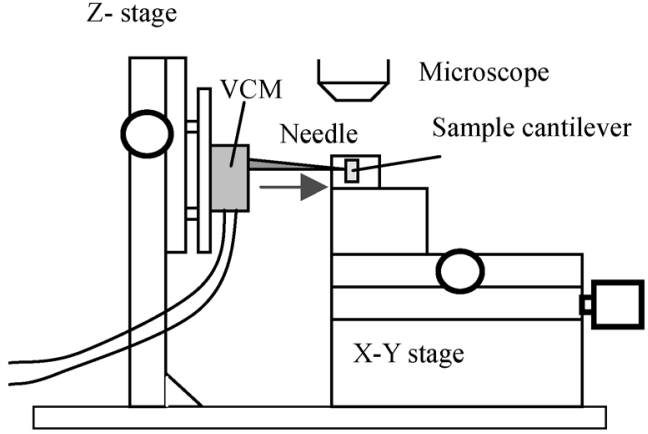

Fig. 1. Deflection measuring setup

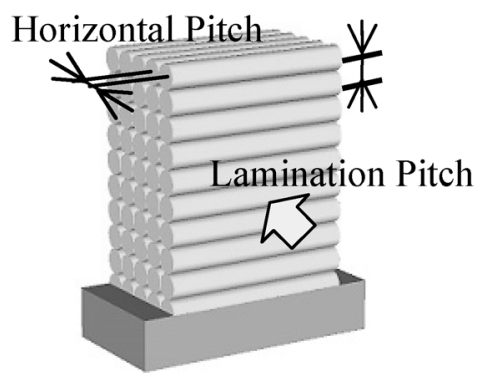

(a) Design data

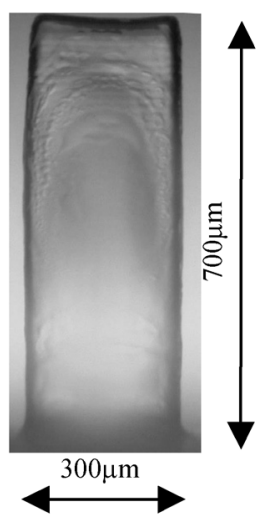

(b) Sample micro cantilever

Fig. 2. Micro cantilever

Table 1. Measurement results of elastic modulus

\begin{tabular}{|c|c|c|c|}
\hline \multicolumn{2}{|c|}{$\begin{array}{c}\text { Fabrication condition } \\
\text { (Laser power, postcure time })\end{array}$} & Elastic modulus $\left(\mathrm{N} / \mathrm{m}^{2}\right)$ & $\begin{array}{c}\text { Standard } \\
\text { deviation }\end{array}$ \\
\hline \hline A & $8.86 \mu \mathrm{W}, 0(\mathrm{~min})$ & $6.62 \times 10^{8}$ & $5.61 \times 10^{7}$ \\
\hline B & $8.86 \mu \mathrm{W}, 20(\mathrm{~min})$ & $8.18 \times 10^{8}$ & $1.45 \times 10^{8}$ \\
\hline C & $8.86 \mu \mathrm{W}, 30(\mathrm{~min})$ & $8.31 \times 10^{8}$ & $1.97 \times 10^{8}$ \\
\hline $\mathrm{D}$ & $8.86 \mu \mathrm{W}, 20(\mathrm{~min}) 10 \mathrm{days}$ after & $7.83 \times 10^{8}$ & $3.26 \times 10^{8}$ \\
\hline $\mathrm{E}$ & $10.30 \mu \mathrm{W}, 0(\mathrm{~min})$ & $9.89 \times 10^{8}$ & $2.85 \times 10^{8}$ \\
\hline $\mathrm{F}$ & $10.30 \mu \mathrm{W}, 20(\mathrm{~min})$ & $1.08 \times 10^{9}$ & $3.26 \times 10^{8}$ \\
\hline
\end{tabular}




\title{
マイクロ光造形法で作製した構造物の機械的特性評価
}

$\begin{array}{llll}\text { 正 員 三輪 } & \text { 昌史* } & \text { 非会員 川口 } & \text { 博史* } \\ \text { 非会員 堂岡 } & \text { 和親* } & \text { 非会員 米山 } & \text { 聡** } \\ \text { 正 員 土谷 } & \text { 茂樹* } & \text { 正 員 越本 } & \text { 泰弘* }\end{array}$

\author{
Mechanical Property Evaluation of Micro Cantilever Fabricated Using Micro-Stereolithography \\ Masafumi Miwa*, Member, Hiroshi Kawaguchi*, Non-member, Kazuchika Douoka*, Non-member, \\ Satoru Yoneyama**, Non-member, Shigeki Tuchitani, Member, Yasuhiro Koshimoto, Member
}

\begin{abstract}
Dependence of elastic modulus of micro cantilever fabricated by micro-stereolithography $(\mu \mathrm{SL})$ on irradiation laser power is investigated in this study. The samples are formed by changing the irradiation laser power of $\mu \mathrm{SL}$ system and postcure processing time. A device for measuring deflection of the micro cantilever and applied load is developed. Then, the elastic moduli of the samples are evaluated from the gradient of the measured load-deflection relation and the formula of the strength of materials. Results show that the elastic modulus of the micro cantilever made by $\mu \mathrm{SL}$ is depend on the irradiation laser power. That is, the mechanical property of micro structures can be controlled by the irradiation laser power and post cure process.
\end{abstract}

キーワード : マイクロ光造形法, 縦弹性係数, マイクロカンチレバー, マイクロマシン

Keywords : 3D Micro Stereo Lithography, Elastic Modulus, Micro Cantilever, Micromachine

\section{1. 緒 言}

近年さまざまな分野でデバイス・センサ等の省電力化・ 高精度化が進展し, 構成部品の小型化や内部構造の微細化 が要求されている。これらを実現するため，半導体プロセ スや LIGA プロセス等さまざまな微細加工技術に関する研 究が行われている。このような小さくて䋊細な構造物を製 作するための技術はいろいろ研究されているが，我々はそ の中でマイクロ光造形法に着目した。マイクロ光造形法に は一光子吸収反応を用いる方法 ${ }^{(1)}$ と二光子吸収反応を用い る方法 ${ }^{(2)}(6)$ がある。二光子吸収反応を用いる方法では加工分 解能が向上するが，設備としては大掛かりな装置になる。 そこで我々は比較的小型の装置で構成できる一光子吸収反 応を用い，これまでにデスクトップサイズのマイクロ光造 形システムを開発した(7)。また，それによって作製した三次 元造形物の造形精度評価を行った。

これまでにマイクロ光造形を用いた微小構造物の作 製(1) (4),(6)や機能性材料であるフォトニッククリスタルの作

\footnotetext{
* 和歌山大学システム工学部

干 $640-8510$ 和歌山市栄谷 930

Faculty of Systems Engineering, Wakayama University

930 Sakaedani, Wakayama, Wakayama 640-8510

** 大阪府立大学大学院

T599-8531 堺市中区学園町 1-1

Osaka Prefecture University

1-1 Galuencho, Nakaku, Sakai 599-8531
}

製(5)が報告されている。一方，マイクロ光造形法によりマイ クロマシンのような駆動を主とするデバイスの設計・開発 に際して重要となるのが構造物の機械的特性である。基本 的にマイクロ光造形法により作製した構造物は高分子素材 であり，この手法の造形原理上，バルク材の高分子素材の 公称值とは異なる特性を示寸事が考えられる。そのためマ イクロ光造形法で作製した構造物の機械的特性を把握する 必要がある。そこで本研究ではマイクロ光造形法で作製さ れた微小構造物の機械的特性評価について, 縦弾性係数の 計測による検討を行った。またマイクロアクチュエータ等 様々な機能を付加した微小構造物をマイクロ光造形法によ って製作するためには, 内部で部分的に異なる縦弾性係数 を持つことも要求される。これを実現するためにはその部 分の材質や形状を変える方法が考えられるが，これにより 製造工程が増加・複雑化したり，作製する構造物の形状・ 材質に制限が加わる等のデメリットが伴う。そこで構造物 作製時の造形条件の一つであるレーザーパワーを変化させ ることによって，構造物の縦弾性係数をコントロールする 可能性についての検討も合わせて行った。

\section{2. 実験方法}

〈2·1〉 マイクロ光造形装置 マイクロ光造形装置の 概略を図 1 に示す。本研究では発振波長が 406nm の半導体 レーザー (ネオアーク(株)TC20－4030S－2F15SU）を使用し 


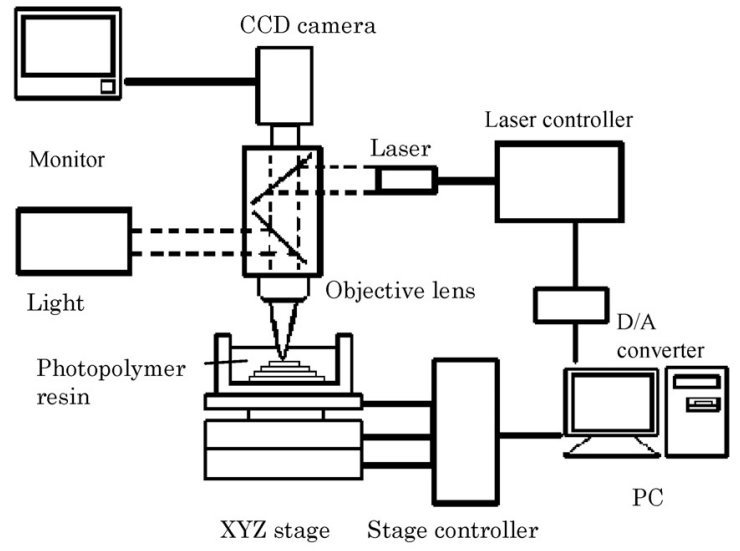

Fig. 1. Experimental setup

Table 1. Composition of photopolymer resin

\begin{tabular}{|c||c|c|}
\hline Name & Chemical name & Company \\
\hline \hline $\begin{array}{c}\text { Photomer-3016 } \\
\text { (oligomer) }\end{array}$ & $\begin{array}{c}\text { Bisphenol-A } \\
\text { epoxy diacrylate }\end{array}$ & SAN NOPCO \\
LIMITED \\
\begin{tabular}{c|c|} 
Photomer-4072-SN \\
(monomer)
\end{tabular} & $\begin{array}{c}\text { Trimethylolpropane } \\
\text { Propoxylate triacrylate }\end{array}$ & $\begin{array}{c}\text { Wako Pure } \\
\text { Chemical } \\
\text { Industries,Ltd }\end{array}$ \\
\hline $\begin{array}{c}\text { Chlorothioxanthone } \\
\text { (Photo initiator) }\end{array}$ & 2-chlorothioxanthone & \multicolumn{1}{|c|}{} \\
\hline
\end{tabular}

た。レーザー光は 2 枚のハーフミラー (エドモンド BJ54824) を通り, 無限遠補正対物レンズ（オリンパス光学工業： NeoSPlan, 開口数:0.75) によって集光され試料に照射され る。この UV レーザーのパワーは約 0〜 $220 \mathrm{~mW}$ の範囲で可 変である。試料である光硬化性樹脂は自作したアルミ製の 樹脂槽に満たし，それを三次元マイクロステージ上のサン プルホルダに載せた。三次元マイクロステージには電動マ イクロモータ (中央精機（株）：AME-25, AME-15）が $X$,

$Y, Z$ 軸それぞれに取り付けられており, 専用コントローラ を介してパーソナルコンピュータで速度設定, 原点復帰, ステップ送り, 非常停止, 現在位置の確認などの制御がで き，任意の三次元形状を描くことができる。この三次元電 動マイクロステージの動作範囲は $X, Y$ 軸ではそれぞれ $25 \mathrm{~mm}, Z$ 軸では $15 \mathrm{~mm}$ である。加工の様子については装置 上部に取り付けられた CCD カメラ（エドモンド： CVC-6811LN）により観測し，VTR で録画した。本研究では 一般的な光造形法のように樹脂の表面付近で硬化させて硬 化層を積層するのではなく, アルミ製の槽に満たした光硬 化性樹脂内部に直接レーザー光を照射し，対物レンズによ ってレーザー光を集光させることによって焦点付近に光強 度の高いピークを生じさせ, 樹脂内部の 1 点のみを選択的 に硬化させることによって三次元構造の形成を行った。

$\langle 2 \cdot 2\rangle$ 光硬化性樹脂 本研究で使用した光硬化性樹 脂は，モノマーとしてサンノプコ株式会社のフォトマー 4072-SN，オリゴマーとしてフォトマー3016, 光重合開始剤 として 2-クロロチオキサントンを用いた（表 1)。またオリ ゴマーとモノマーの配合割合は，扱いやすさと開始剤を極 a)

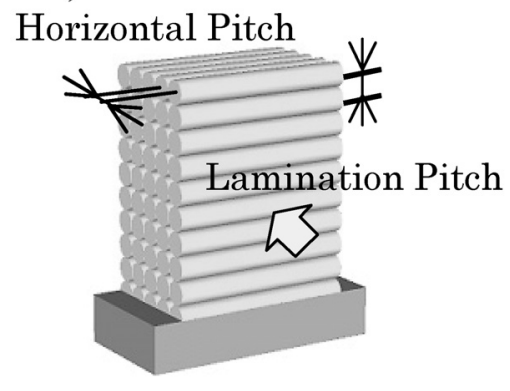

(a) Design data b)

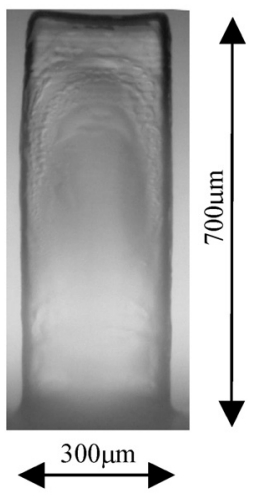

(b) Sample micro cantilever
Fig. 2. Micro cantilever

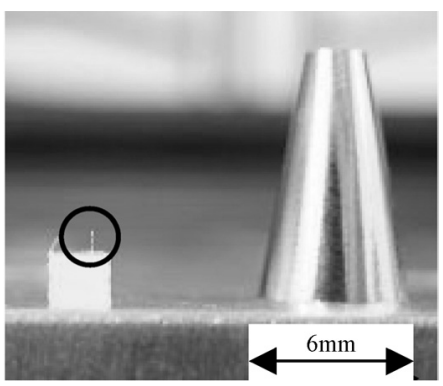

Fig. 3. Micro cantilever

力少なくすることを考慮して試行した結果，フォトマー 3016 : フォトマー4072-SN=1 : 3 とした。また光重合開始剤 は実際に濃度を変更して造形を行い, 最適な開始剤濃度を 検討した結果， $3.13 \times 10^{-6} \mathrm{~mol} / \mathrm{g}$ とした。

〈2·3〉試料の作製方法 たわみ測定実験の試料とし て本マイクロ光造形装置で図 2 に示すようなマイクロカン チレバーを作製した。断面形状の整ったマイクロカンチレ バー作製のため, 高さ方向に積み上げていく形でマイクロ カンチレバーを作製した。作製された試験片を図 3 に示す。

図中の黒丸で囲まれた部分が試験片であり，右は比較の ためのボールペンのペン先カバーである。

試験片のサイズは幅 $300 \mu \mathrm{m}$, 厚み $50 \mu \mathrm{m}$, 高さ $700 \mu \mathrm{m}$ と した。これは $300 \mu \mathrm{m}$ の長さの微小棒状硬化物を平行に $5 \mu \mathrm{m}$ 間隔で 11 本並べ，こうしてできた 1 層分の硬化層を垂直方 向に積層ピッチを $10 \mu \mathrm{m}$ で積層して作製した。

試験片の作製条件を表 2 に示寸。サンプル A と E の組み 合わせと, サンプル B と F の組み合わせは造形時のレーザ ーパワーが縦弾性係数へ及ぼす影響を調べるために作製し た。また，サンプル A, B, Cの組み合わせはポストキュア 時間の縦弾性係数への影響を調べるために作製した。サン プル B と D の組み合わせは縦弾性係数の経時変化を調べる ために作製した。

〈2・4〉たわみ測定装置 マイクロ光造形法でマイク ロアクチュエータやマイクロマシンなどを設計・作製する にあたり，材料となる樹脂の機械的特性を把握する必要が ある。本研究ではたわみ測定装置を構成し, 材料である光 
Table 2. Fabrication condition of test samples

\begin{tabular}{|c|c|c|c|c|c|}
\hline Sample & Laser Power & Scan Velocitty & Pitch & $\begin{array}{l}\text { Postcure } \\
\text { time(min) }\end{array}$ & Remark \\
\hline $\mathrm{A}$ & \multirow{4}{*}{$8.86 \mu \mathrm{W}$} & \multirow{6}{*}{$73 \mu \mathrm{m} / \mathrm{s}$} & \multirow{6}{*}{$\begin{array}{l}\text { Horizontal Pitch } 5 \mu \mathrm{m} \\
\text { Lamination Pitch } 10 \mu \mathrm{m}\end{array}$} & 0 & \\
\hline $\mathrm{B}$ & & & & 20 & \\
\hline $\mathrm{C}$ & & & & 30 & \\
\hline $\mathrm{D}$ & & & & 20 & Leaved for 10 days after fabrication \\
\hline $\mathrm{E}$ & \multirow{2}{*}{$10.30 \mu \mathrm{W}$} & & & 0 & \\
\hline $\mathrm{F}$ & & & & 20 & \\
\hline
\end{tabular}

a)

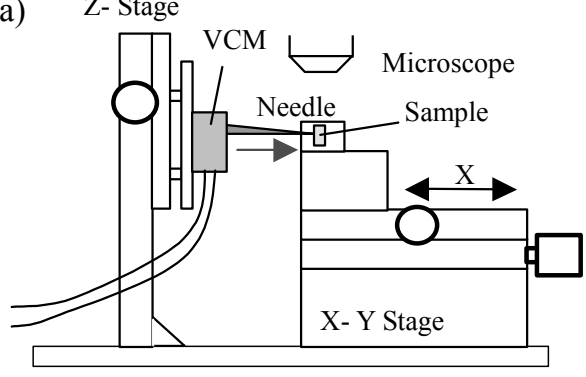

(a) Diagram of Setup

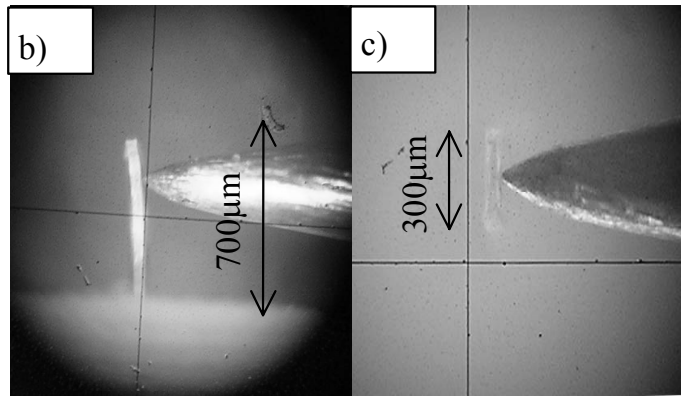

$\begin{array}{ll}\text { (b) Top view of loading part } & \text { (c) Side view of loading part }\end{array}$

Fig. 4. Deflection measuring setup

硬化性樹脂の縦弾性係数の測定を試みた。たわみ測定装置 の概略を図 4 に示す。このたわみ測定装置ではサンプルに 荷重をかけるアクチュエータとして CD 再生機などに用い られているボイスコイルモータ（出力・入力電流比：0.379 $\mathrm{mN} / \mathrm{mA}$ ）を採用した。測定は以下のように行った。作製し た試料をたわみ試験機の XY ステージ上に固定し, Z 軸ステ ージに取り付けられたボイスコイルモータに針（先端の極 率半径 $50 \mu \mathrm{m}$, 材質：鋼）を取り付けた。試料と針とが接触 する様に各ステージを調整する。試料と針とが接触したと きの針の変位を 0 とし，ボイスコイルモータに電流を流し て荷重をかけていく。すると電流に応じて針に変位が生じ, それに押されて試料にたわみが生じる。次に, XY 軸ステー ジの X 方向を移動させて試験片を針に押し付けると, 試験 片のたわみによって発生する反力により，針が押し返され る。そして, 測微顕微鏡で観察しながら針の変位が 0 にな るまで XY 軸ステージの X 方向を移動させる。このときの 移動量が試料のたわみとなる。このたわみを, ボイスコイ

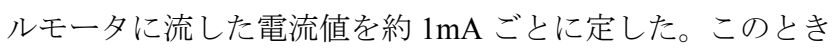
のボイスコイルモータの出力（試験片に掛かる荷重）は, 事前に測定した出力一電流特性（変位０におおるボイスコ イルモータの出力と電流の関係）から求めることができる。 また, 同じ測微顕微鏡で縦弾性係数を算出するために必要 なマイクロカンチレバーの各部の長さを測定した。ボイス コイルモータに流れる電流と力の特性を元に図 6 に示すよ うなマイクロカンチレバーのたわみと荷重の関係のグラフ を得た。

\section{3. 縱弾性係数の算出}

たわみ測定試験におけるカンチレバーと針との接触時の
様子を図 5 に，たわみ測定の結果の例を図 6 に示す。

図 6 のグラフよりこの試料のバネ定数を回帰直線の傾き として求め, 片持ち梁に 1 つの集中荷重を加えた時の先端 のたわみとの関係式 ${ }^{(8)}$ より縦弾性係数を求めた。

まず，カンチレバーをばねとして考えるとばねの変位 $y$ と荷重 $W$ の式は

$$
W=K y
$$

と表せる。ここで，Kはばね定数である。

一方, カンチレバーのたわみの式は

$$
y=-\frac{a^{2}}{6 E I}(2 a+3 b) \times W
$$

となる。ここで, $y$ はたわみ, $a$ はカンチレバーの根元から 集中荷重を加えた地点までの距離, $b$ は集中荷重を加えた地 点から梁の先端までの距離, $E$ は縦弾性係数, $I$ は断面二次 モーメントである。

式(1), 式(2)より縦弾性係数 $E$ を求めると,

$$
E=\frac{K a^{2}(2 a+3 b)}{6 I}
$$

となる。たわみ測定試験で得たグラフの傾きを $K$, マイクロ カンチレバーの各部の長さを $a, b, p, h$ として式(3)に代 入すると縦弾性係数が求められる。

マイクロ光造形法で作製したカンチレバーのたわみ試験 を行う前に, 本たわみ試験装置とこれまで説明した縦弾性 係数の導出理論の信頼性を確かめるための予備実験を行っ た。試験片は厚さ約 $0.1 \mathrm{~mm}$ の銅箔を幅 $1.4 \mathrm{~mm}$, 長さ $15 \mathrm{~mm}$ 程度の短冊形に切断したものを用いた。6 本の試験片に対し て先に述べた手順で縦弾性係数の測定を行ったところ, 平 均縦弾性係数が $1.17 \times 10^{11} \mathrm{~N} / \mathrm{m}^{2}$, 標準偏差は $2.34 \times 10^{10}$ であ った。これは室温での銅の縦弾性係数である $1.22 \times 10^{11} \mathrm{~N} / \mathrm{m}^{2}$ 


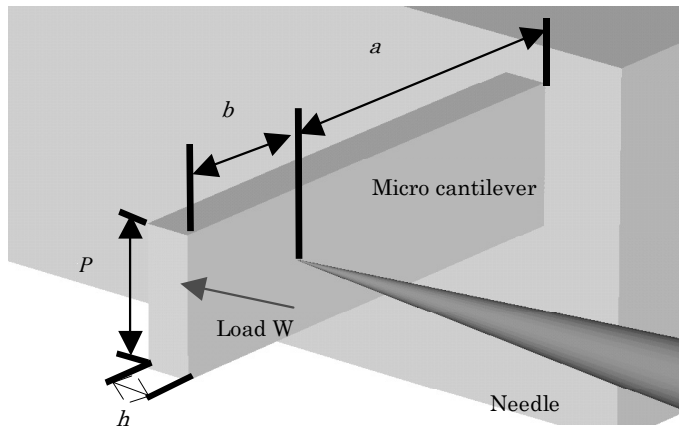

Fig. 5. Deflection measurement

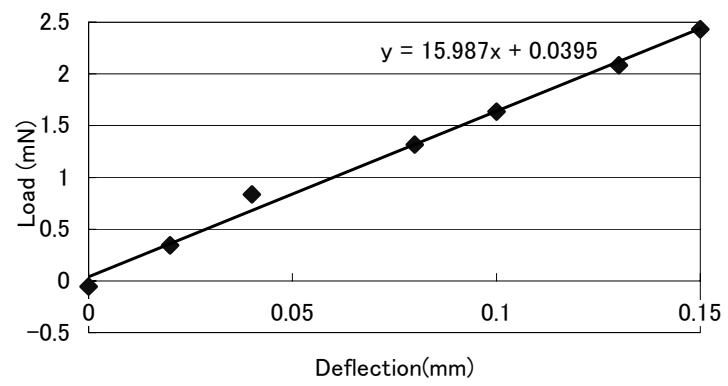

Fig. 6. An example of deflection vs. load plot

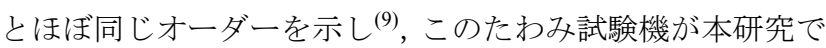
十分使用できることを確認した。

また，たわみ試験は試験片の側面から針の先端で荷重を かけるため，試験中に高分子素材である試験片に針の先端 が刺さったり埋没したりすると測定の精度が下がる。その ため本研究ではたわみ試験に用いる試験片の作製条件の中 で最も重合の程度が低く，より小さい荷重で針先が刺さる と考えられる,レーザーパワーが $8.86 \mu \mathrm{W}$ でポストキュア処 理を行わない条件で作製したマイクロカンチレバーに対し, たわみ試験で用いた針と同様にして作製した針を用いて側 面から荷重をかけ,試験片表面に針の先端が埋没する時の荷 重を調べた。その結果として試験片にかける荷重が約 $5 \mathrm{mN}$ で初めて試験片側面に針の先端による傷が確認され，それ 以下では針による傷は確認されなかった。本実験ではたわ み試験で試験片にかける荷重は $2.5 \mathrm{mN}$ までとしたため，針 が試験片に刺さる・埋没するなどのことは起きていない。 今回の実験では, サンプルのたわみと荷重はそれぞれ $0.15 \mathrm{~mm}, 2.5 \mathrm{mN}$ までの範囲で測定した。また，全てのサン プルで同じ条件で測定を行った。

\section{4. 縦弾性係数の測定における粘弾性の影響}

マイクロ光造形法により作製した試験片は高分子素材で ある。そのためこの試験片は物体に与えた応力とそれによ るひずみの関係が時間に関係なく一定で可逆的な変形をす る弾性体と, 変形に必要な応力がひずみの量ではなくひず み速度によって決定する粘性体の両方の性質を持つ粘弾性 と呼ばれる性質を持つ(10)。そこでたわみ試験に用いている試 験片と同じ作製条件・サイズの試験片を用いて図 7 の実験

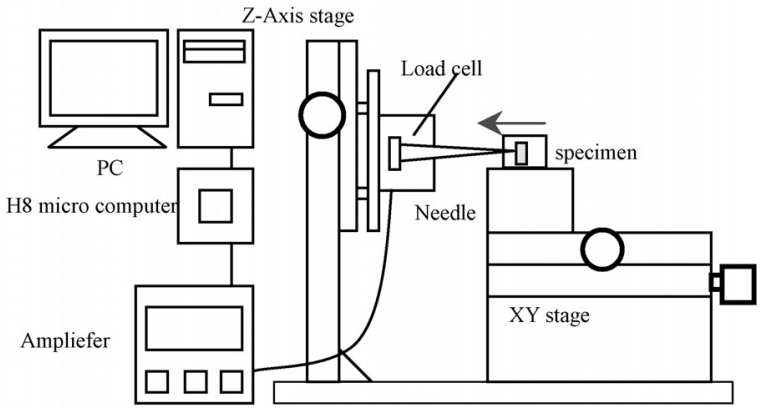

Fig. 7. Stress relaxation measurement setup

装置により，たわみ試験における粘弾性の影響を調べた。 試験片にはレーザーパワー $8.86 \mu \mathrm{W}$ で作製し 20 分間のポ ストキュア処理を行ったマイクロカンチレバーを用いた。 測定は試験片を固定したステージを図中の矢印の方向に約 1 秒で移動させ, ひずみゲージを用いた荷重センサであるロ ードセル（共和電業株式会社 LVS-5GA）に取り付けた針に 試験片となるマイクロカンチレバーを押し付け, 一定の変 位をかける。その時に試験片が針を押し返す反力が応力緩 和により時間と共に減少する過程を測定した。

荷重をかけてから時間と共に試験片の反力が減少する一 例を図 8 に示す。図はPC によるサンプリング開始から約 5 秒後に一定変位を与え, それ以降約 55 秒間の反力の推移の 様子である。

この荷重值と実験中に測定した試験片の断面寸法である $p$ と $h$, 試験片の根元から荷重をかけた点までの距離 $a$ から 式(4)を用いて試験片の根元にかかる最大応力 ${ }^{(10)}$ に換算し た。

$$
\sigma=\frac{6 W a}{p h^{2}}
$$

$(\sigma$ :試験片の根元にかかる最大応力, $W$ : 試験片にかけた荷 重, $a$ :試験片の根元から荷重をかけた点までの距離, $p$ :試験 片断面の高さ, $h$ :試験片断面の幅)

こうして荷重值から応力值を求め, 初期応力を 1 とした 時の応力緩和曲線を図 9 に示す。これは複数のサンプルの 測定結果を示している。この結果，荷重をかけてから約 30 秒までの間に初期の応力の $50 \%$ ～60\%程度まで緩和するこ とが分かった。また, 最終的に 400 秒後も応力は 0 になら ず，データごとにばらつきはあるものの初期にかけた応力 の $40 \%$ 前後の值で緩和は止まり, 以降はほぼ一定の応力を 保ちつづけた。

本研究のたわみ試験では荷重をかけてから試験片のたわ みを測定し，記録までの時間を約 30 秒以内で行っている。 しかし 30 秒後に再度, 測微顕微鏡で試験片を観察しても試 験片先端の位置の変化は見られなかった。この変位は目視 できない程度のものであると考えている。また, 本実験で 行ったたわみ試験の結果として得られた縦弾性係数は試験 片の粘弾性によって 40\%〜 50\%程度応力が緩和した状態で 測定した值であると考えられる。 


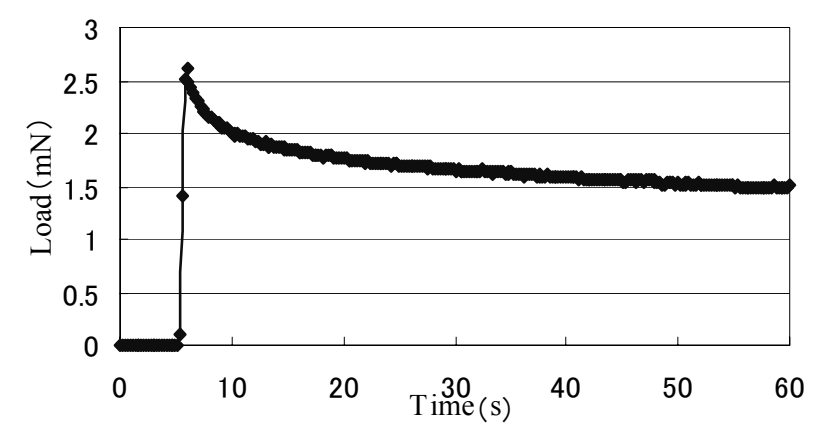

Fig. 8. Reactive force change

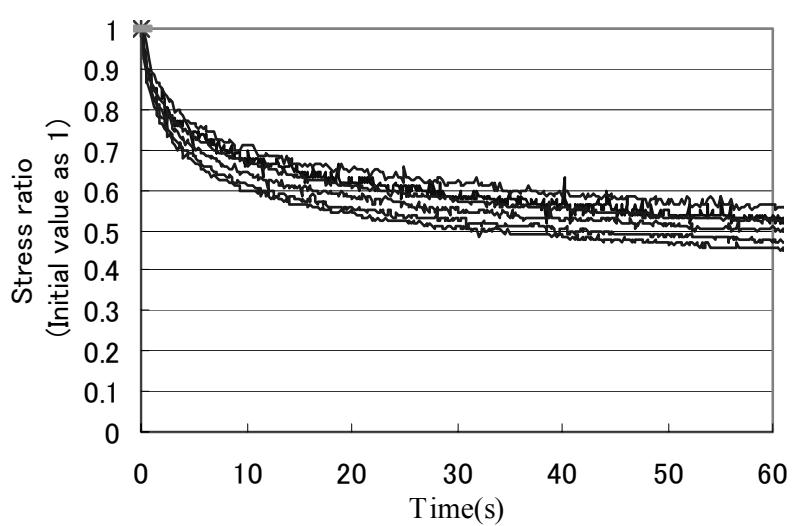

Fig. 9. Stress relaxation of a sample micro cantilever

Table 3. Measurement results of elastic modulus

\begin{tabular}{|c|c|c|c|}
\hline \multicolumn{2}{|c|}{$\begin{array}{c}\text { Fabrication condition } \\
\text { (Laser power, postcure time ) }\end{array}$} & Elastic modulus (N/ $\left.\mathrm{m}^{2}\right)$ & $\begin{array}{c}\text { Standard } \\
\text { deviation }\end{array}$ \\
\hline \hline A & $8.86 \mu \mathrm{W}, 0(\mathrm{~min})$ & $6.62 \times 10^{8}$ & $5.61 \times 10^{7}$ \\
\hline B & $8.86 \mu \mathrm{W}, 20(\mathrm{~min})$ & $8.18 \times 10^{8}$ & $1.45 \times 10^{8}$ \\
\hline C & $8.86 \mu \mathrm{W}, 30(\mathrm{~min})$ & $8.31 \times 10^{8}$ & $1.97 \times 10^{8}$ \\
\hline D & $8.86 \mu \mathrm{W}, 20(\mathrm{~min}) 10 \mathrm{days}$ after & $7.83 \times 10^{8}$ & $3.26 \times 10^{8}$ \\
\hline E & $10.30 \mu \mathrm{W}, 0(\mathrm{~min})$ & $9.89 \times 10^{8}$ & $2.85 \times 10^{8}$ \\
\hline F & $10.30 \mu \mathrm{W}, 20(\mathrm{~min})$ & $1.08 \times 10^{9}$ & $3.26 \times 10^{8}$ \\
\hline
\end{tabular}

\section{5. 縦弾性係数測定}

〈5·1〉 縦弾性係数のレーザーパワー依存性 表 2 に 示す条件のサンプルを, A-D の試験片はそれぞれ 10 個ずつ, E，F の試験片は 15 ずつ作製して縦弾性係数を測定した。そ の結果を表 3 に示す。

レーザーパワーを $8.86 \mu \mathrm{W}$ と $10.30 \mu \mathrm{W}$ の 2 条件で作製し, 共にポストキュア処理を行わない条件 A と条件 E の縦弾性 係数を比較した結果, 条件 A で作製した試験片の平均縦弾 性係数が $6.62 \times 10^{8} \mathrm{~N} / \mathrm{m}^{2}$ であるのに対し，よりレーザーパワ 一の大きな条件 E で作製した試験片のほうが $9.89 \times 10^{8} \mathrm{~N} / \mathrm{m}^{2}$ と約 $50 \%$ 大きな縦弾性係数を示した。さらに作製後にポス トキュア処理を 20 分間行った条件 B と条件 F のサンプルが 示すように，条件 B の試験片が $8.18 \times 10^{8} \mathrm{~N} / \mathrm{m}^{2}$ ，条件 F の試 験片が $1.08 \times 10^{8} \mathrm{~N} / \mathrm{m}^{2}$ とレーザーパワーの大きい試験片の方 が約 30\%大きい值を示すことが分かった。このことからマ イクロ光造形法において, 作製した構造物は作製時のレー ザーパワーが大きいほど縦弾性係数も大きくなり，構造物 の縦弾性係数は作製時のレーザーパワーに依存する事がわ かった。さらにポストキュア処理により構造物の内部の重 合を完全にした後でもこの依存性が残ることが分かった。 この事はマイクロ光造形法を用いて構造物を作製するにあ たり，作製中にレーザーパワーを变化させることで任意の 部分の縦弾性係数をコントロールできる可能性を示してい る。この理由については作製時のレーザーパワーが $8.86 \mu \mathrm{W}$ の場合と $10.30 \mu \mathrm{W}$ の場合では構造物の内部の状態が異な り，またその違いがポストキュア処理後も残るためである
と考えられる。光重合においては, 特に一光子吸収の場合 照射されるレーザー光の強度とそれによって生じる硬化部 分のサイズが比例する。図 10 は造形時の硬化部分の模式図 である。図 10(b)の方がレーザーパワーが大きく, 硬化部分 のオーバーラップも大きくなっている。このオーバーラッ プ部分の大きさの違いが内部構造の違いとなり, 縦弾性係 数が作製時のレーザーパワーに依存する原因だと考えられ る。また，この内部構造はレーザー光焦点で生成されたも ので硬化反応が終了しており, ポストキュア後でも構造が 維持されるため，作製時のレーザーパワー依存性は保持さ れると考えられる。今後この内部構造については光学顕微 鏡や原子間力顕微鏡を用いた内部と表面の観察により検証 を行う。

また，比較のために 2 枚のスライドガラスで同じサンプ ル樹脂を挟み, 紫外線ランプの紫外線照射のみで固化させ たサイズ約 $0.3 \times 2.3 \times 15.3 \mathrm{~mm}$ のカンチレバーを 10 本作製し 同様の試験を行い縦弾性係数を算出したところ， $1.53 \times$ $10^{9} \mathrm{~N} / \mathrm{m}^{2}$ であった。これはマイクロ光造形法を用いて作製し たカンチレバーの縦弾性係数の約 10 倍である。このように 同じサンプル樹脂を用いたにも関わらず縦弾性係数に差が 生じたのであるが，この理由については今後検討する。

〈5·2〉縦弾性係数に対するポストキュア処理時間の効

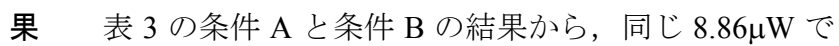
作製した試験片でも,ポストキュアを行わない試験片は 6.62 $\times 10^{8} \mathrm{~N} / \mathrm{m}^{2}$ であったのに対し,ポストキュア処理を 20 分間行 った場合は $8.18 \times 10^{8} \mathrm{~N} / \mathrm{m}^{2}$ と約 $20 \%$ 以上縦弾性係数が大きく なることが分かった。このことからポストキュア処理が構 
(a)

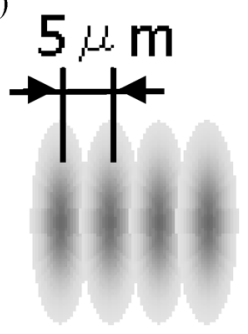

(a) $8.86 \mu \mathrm{W}$ (b)

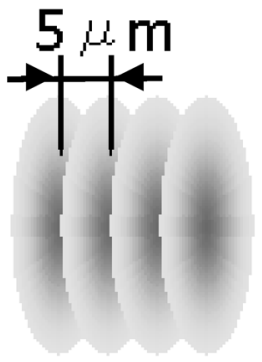

(b) $10.30 \mu \mathrm{W}$
Fig. 10. Overlap of polymerization Fabrication laser power

造物の造形時のレーザー照射のみでは不十分な構造物内部 の重合を進め,それが構造物の縦弾性係数を高めることに有 効であることが示された。

また表 3 の条件 Cからも分かるように $8.86 \mu \mathrm{W}$ のレーザー パワーで作製し 30 分間のポストキュア処理を行った試験片 の縦弾性係数は $8.31 \times 10^{8} \mathrm{~N} / \mathrm{m}^{2}$ であった。これはポストキュ ア処理時間が 20 分間の条件 B の結果とほぼ同じ值であっ た。このことから試験片の重合が 20 分間のポストキュア処 理で十分に完了し，この時間以上紫外線の露光を続けても 構造物の内部の構造に変化がないことを表している。また, たわみ試験で使用した試験片のサイズである $300 \mu \mathrm{m} \times$ $50 \mu \mathrm{m} \times 900 \mu \mathrm{m}$ 程度の構造物であれば本実験で使用した紫外 線ランプで 20 分間程度の紫外線露光で十分内部まで重合が 完了することが分かった。

$\langle 5 \cdot 3\rangle$ 縱弾性係数の経時変化 表 3 の条件 Dより, 作製後にポストキュア処理を 20 分間行った試験片を約 10 日保存した後に縦弾性係数を測定したところ，作製から 1 日後の試験片の縦弾性係数と比較して 4\%程度低い結果が 得られた。しかしレーザーパワーやポストキュア時間を変 えて作製した場合と比べてほとんど変化しないといえる。

これまでの結果からレーザーパワー $8.86 \mu \mathrm{W} て ゙$ 作製した試 験片にポストキュア処理を 20 分行った条件では，これを行 わない条件よりも縦弾性係数が大きくなった。よって紫外 光の露光により縦弾性係数が大きくなるという結果を考慮 すると, 構造物作製後にポストキュア処理を行い, 内部ま で完全に重合させることは, 構造物の縦弾性係数を高くす るためだけでなく, 重合を完了させることで構造物の縦弾 性係数が経時変化することを防ぐために有効であることが 分かった。これによりマイクロ光造形法を用いて微小デバ イスの設計・作製を視野に入れた場合，ポストキュア処理 が縦弾性係数やその安定性の面でも重要であることを確認 した。

\section{6. 結 論}

マイクロ光造形法でマイクロカンチレバーを作製し，こ れを試験片としてたわみ試験を行い，その縦弾性係数を測 定した。作製条件の一つであるレーザーパワーを変えて作 製した試験片の縦弾性係数の比較を行った結果, マイクロ
光造形法で作製したマイクロカンチレバーその縦弾性係数 は，作成時のレーザーパワーに依存することが判明した。 さらにポストキュア処理により構造物の内部の重合を完全 にした後でもこの依存性が残ることが分かった。この事は マイクロ光造形法を用いて構造物を作製するにあたり，作 製中にレーザーパワーを変化させることで任意の部分の縦 弾性係数をコントロールできる可能性を示している。この 縦弾性率の変化の原因については, 今後検討を行う。

\section{謝 辞}

本研究の遂行にあたり, 助言・援助をいただきました故・ 元和歌山大学システム工学部教授 金子礼三氏に感謝いた します。

本研究で使用した光硬化樹脂はサンノプコ株式会社，三 洋化成工業株式会社, コグニスジャパン株式会社より提供 していただきました。また, 本研究の一部は平成 14 年度科 学研究費補助金（若手（B））１4750187 の助成により実行い たしました。ここに感謝の意を表します。

(平成 18 年 5 月 2 日受付, 平成 18 年 9 月 25 日再受付)

\section{文献}

(1) M. Horiyama, H. B. Sun, M. Miwa, S. Matsuo, and H. Misawa : "Three-Dimensional Microstructure Created by Laser Microfabrication Technology”, Jpn. J. Appl. Phys., Vol.38, pp.L212-L215 (1999)

(2) S. Maruo and K. Ikuta : "Three-dimensional microfabrication by use of single-photon-absorbed polymerization", Appl. Phys. Lett., Vol.76, No.19, pp.2656-2658 (2000)

( 3 ) H.-B. Sun, T. Kawakami, Y. Xu, J. Yu, S. Matsuo, H. Misawa, M. Miwa, and R. Kaneko : "Real three-dimmensional microstructures fabricated by photopolymerization of resins through two-photon absorption", Optics Letters, Vol.25, No.15, pp.1110-1112 (2000)

(4) M. Miwa, S. Juodkazis, T. Kawakami, S. Matsuo, and H. Misawa : "Femtosecond two-photon stereo-lithography", Appl. Phys. A (2001) / DOI: $10.1007 / \mathrm{s} 003390100934$

( 5 ) K. K. Seet, V. Mizeikis, S. Juodkazis, and H. Misawa : "Spiral three-dimensional photonic crystals for telecommunications spectral range", Appl. Phys. A (2005) / DOI: 10.1007/s00339-005-3459-y

(6) S. Juodkazis, V. Mizeikis, K. Seet, M. Miwa, and H. Misawa : "Twophoton lithography of nanorods in SU-8 photoresist", Nanotechnology Vol.16, pp.846-849 (2005), doi:10.1088/0957-4484/16/6/039

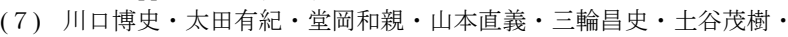
越本泰弘・金子礼三・三澤弘明 :「マイクロ光造形法で作製した微小 構造物の機械的特性評価」, 日本実験力学会第 1 回研究発表講演会論 文集, pp.291-294 (2001)

（8）日本機械学会編：「(新版)機械工学便覧基礎編 A4 材料力学」, pp.109-155 (1994)

(9) 太田友弥:「新版材料力学」, 山海堂 (1996)

(10) 岡 小天 : 「レオロジー入門」, pp138-196(1973)

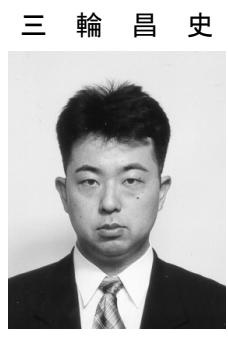

（正員） 1994 年徳島大学大学院博士前期課程 修了。1996 年徳島大学大学院博士後期課程中 退。1996 年和歌山大学助手。博士 (工学)。主 としてマイクロマシン, 機械工学に関する研究 に従事。 


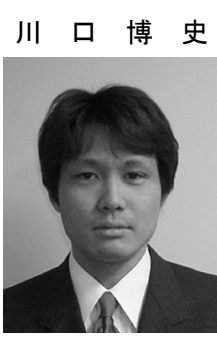

堂 岡 和 親

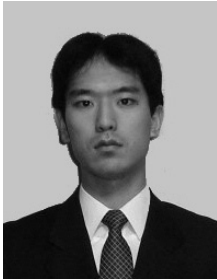

米山聡

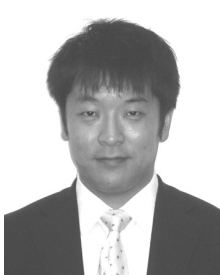

(非会員) 2000 年和歌山大学システム工学部光 メカトロニクス学科卒。2002 同大学院システム 工学研究科システム工学専攻修了。修士（工 学)。在学中は主にマイクロ光造形法の研究に 従事。 メカトロニクス学科卒。現在同大学院システム 工学研究科システム工学専攻。学士(工学)。在 学中は主にマイクロ光造形法の研究に従事。

（非会員）1997 年青山学院大学大学院博士前期 課程修了。1998 年青山学院大学大学院博士前期 課程退学。1 998 年青山学院大学助手。2000 年 和歌山大学助手。2004 年大阪府立大学講師。主 として実験応力解析に関寸る研究に従事。
土 谷 茂 樹

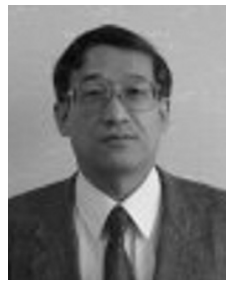

越本泰弘

（正員） 1979 年大阪大学大学院基礎工学研究 科物理系専攻物性学分野 (修士課程) 修了。1979 年から（株）日立製作所 日立研究所にて各種 センサの研究開発に従事。1996 年和歌山大学シ ステム工学部に採用され, 現在同教授。工学博 士。マイクロトライボロジー及びマイクロマシ ンの研究に従事。応用物理学会, 日本卜ライボ ロジー学会。

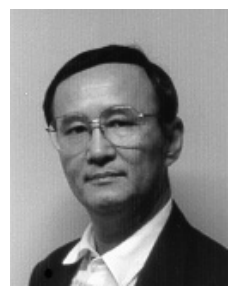

（正員） 1968 年静岡大学文理学部理学科卒。 同年電電公社（現 NTT）電気通信研究所入社。 1995 年 NTT アドバンステクノロジ (株)。1999 年和歌山大学システム工学部教授現在に至る。 現在, 磁気マイクロマシンおよびセンシングデ バイスの研究に従事。IEEE, 日本応用磁気学会 各会員，電子情報通信学会フェロー。 